\section{$P-10$. 矯正治療による咬合力の変化についての研究}

\section{○藤田 邦彦·大木 淳·山田建二郎}

九歯大 $\cdot$ 菌矯正

\section{目的}

矯正治療の目的は機能の回復および向上と形態的改善 が挙げられる．形態的改善についてはこれまで数多くの 報告がなされているが, 機能的改善についての報告は数 少ない，今回演者らは矯正治療が機能の変化にどのよう な影響を与えているかを知るために，治療前後の咬合力 を測定し，咬合力の推移から機能検査を行った.

方法

被験者は成人女性 7 人（本学学生）で, 治療前後（治 療後之は装置撤去後）の各歯の咬合最大負担力（以後, 咬合力と呼ぶ）を測定した。咬合力の測定は各歯の歯冠 に金属のアダプターを装着し, 各歯 5 回づつ計測した内 の最大值をその歯の咬合力とした，治療前後の歯軸変化 は，治療後の各歯歯冠上に金属線を㐘軸延長線上にレジ ンで固定した歯冠キャップを作製し，治療前後の模型に 装着し計測した。 また, 各被験者の動的治療期間, Ideal arch 装着期間, 装置撤去後の期間を調查し, 治療 前後の咬合状態の診查も行い, 治療前後の咬合力との関 連性について検討した。

\section{結果}

(1)咬合力は治療後増加する症例が多かった．(2)装置撤 去後の期間が長い（1 年以上）症例に咬合力の増加する

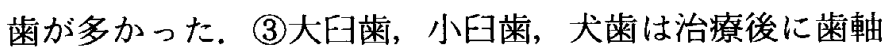
が整直すると咬合力は増加し，より傾斜すると咬合力は 減少する歯が多かった。しかし，前歯においては治療に よる畨軸変化との関連性は見られなかった。

考察

矯正治療中の歯をとりまく歯周組織は歯根膜の拡大等 により，本来の機械的支持機能を維持できず，咬合力が 低下することは知られている．動的治療後から保定期間 中に亘る，正常な歯周組織への回復は咬合力の回復を意 味し，加えて，歯軸の整直は咬合力の增加をもたらすと 考えられる，本研究において，治療後の期間が長い症例 に咬合力の増加が見られたことは，蒾軸の整直に加え て，正常な歯周組織の回復過程と大きな関係があること が推察された.

\section{$\mathrm{P}-11$. 顎関節症患者用問題志向型診療録の試作亡検討}

\begin{tabular}{|c|c|c|c|c|}
\hline ○鱒見 & 進一* & 守川 雅男* & ·世良 & 優裕 ${ }^{* *}$ \\
\hline 内田 & 康也 ${ }^{* *}$ & 昌嗣 *** & - 福田 & 仁一*** \\
\hline 黒川 & 英雄 ${ }^{* * * *}$ & 稳 $* * * *$ & · 今村 & 佳樹 ${ }^{\dagger}$ \\
\hline 仲西 & 修 ${ }^{\dagger}$ & 玲子 ${ }^{\dagger+}$ & ·山田建 & 击二郎 ${ }^{\dagger+}$ \\
\hline
\end{tabular}

顎関節症患者に対する診查·診断・治療は各科の連携 によるチームアプローチが必須であり，すでに実践して いる大学病院も数施設存在している. 本学においては, 各科協力の下でカンファレンスを開催するようになり， チームアプローチあ活発になってきた. しかしながら， 過去にわれわれが作成した顎関節症プロトコールは簡易 的なものであり，高次医療機関として，また，時代の流 れに則って患者の立場に立脚した診療録の作成が急務と なった。今回，顎関節症患者用問題志向型診療録を試作 したので紹介する。

本診療録は, 現在, 九州歯科大学顎関節症チームアプ ローチで使用しているプロトコールをべースに，UCLA Pain Management Center が使用している PODR おょ び九州㐘科大学附属病院㐘科診療録を参考にして作成し た。本診療録はPOSに則り，基礎デー夕，問題リス 卜, 初期プラン, 経過記録, 退院時要約の 5 項目 12 枚 から構成されている. 詳細は以下のとおりである. (1)基 礎データ: 患者の生活像, 病歴聴取のほか, 診查項目と して, 姿勢·顔貌, 筋触診, 顎運動, 関節雑音, 疼痛誘 発テスト, ジョイントプレイテスト, 咬合診查, 咬合様 式, 軟組織の診査, $\mathrm{X}$ 線検査. (2)問題リスト：狭義の問 題リスト, 常用薬剤, 他医療機関での治療, アレル ギー. (3)初期プラン: 監查, 追加検查, 治療プラン, 患 者教育. (4)経過記録：SOAP に則って記入する形式. (5)退院時要約：基礎デー夕, 初診時の問題リスト, 治 療, 現在の状態, 要約. また, 各チャート用紙を色分け にし，項目別検索の容易化を図ったが，今後さらに改良 する点があると思われるので, 各科の御意見·御批判を 頂きより良い診療録を完成したいと考えている. 